\title{
Assisted Migration Field Tests in Canada and Mexico: Lessons, Limitations, and Challenges
}

\author{
Cuauhtémoc Sáenz-Romero ${ }^{1, *(1)}$, Greg $\mathrm{O}^{\prime} \mathrm{Neill}^{2} \oplus$, Sally N. Aitken ${ }^{3}$ and Roberto Lindig-Cisneros ${ }^{4}$ \\ 1 Instituto de Investigaciones sobre los Recursos Naturales (INIRENA), \\ Universidad Michoacana de San Nicolás de Hidalgo (UMSNH), Av. San Juanito Itzícuaro s/n, \\ Col. Nueva Esperanza, Morelia 58337, Michoacán, Mexico \\ 2 British Columbia Ministry of Forests, Lands and Natural Resource Operations and Rural Development, \\ Vernon, BC V1T2X5, Canada; greg.oneill@gov.bc.ca \\ 3 Centre for Forest Conservation Genetics and Department of Forest and Conservation Sciences, \\ Faculty of Forestry, University of British Columbia, 3041-2424 Main Mall, Vancouver, \\ BC V6T1Z4, Canada; sally.aitken@ubc.ca \\ 4 Instituto de Investigaciones en Ecosistemas y Sustentabilidad, \\ Universidad Nacional Autónoma de México (UNAM), Morelia 58190, Michoacán, Mexico; \\ rlindig@iies.unam.mx \\ * Correspondence: csaenzromero@gmail.com
}

Citation: Sáenz-Romero, C.; O’Neill, G.; Aitken, S.N.; Lindig-Cisneros, R. Assisted Migration Field Tests in Canada and Mexico: Lessons, Limitations, and Challenges. Forests 2021, 12, 9. https://dx.doi.org/10.3390/ f12010009

Received: 28 November 2020 Accepted: 21 December 2020 Published: 23 December 2020

Publisher's Note: MDPI stays neutral with regard to jurisdictional claims in published maps and institutional affiliations.

Copyright: (c) 2020 by the authors. Licensee MDPI, Basel, Switzerland. This article is an open access article distributed under the terms and conditions of the Creative Commons Attribution (CC BY) license (https: / / creativecommons.org/ licenses/by/4.0/).

\begin{abstract}
Assisted migration of forest tree populations through reforestation and restoration is a climate change adaptation strategy under consideration in many jurisdictions. Matching climates in which seed sources evolved with near future climates projected for plantation sites should help reduce maladaptation and increase plantation health and productivity. For threatened tree species, assisted migration outside of the species range could help avert extinction. Here, we examine lessons, limitations, and challenges of assisted migration through the lens of three assisted migration field trials of conifers in Canada and Mexico: Pinus albicaulis Engelm., an endangered subalpine tree species in the mountains of western North America; the Picea glauca (Moench) Voss $\times$ P. engelmannii Parry ex Engelm hybrid complex, of great economic and ecological importance in western Canada, and Abies religiosa (Kunth) Schltdl. \& Cham., a tree species that provides overwintering sites for the monarch butterfly. We conclude that: (a) negative impacts of climate change on productivity of Picea glauca $\times$ P. engelmannii may be mitigated by planting seed sources from locations that are $3{ }^{\circ} \mathrm{C}$ mean coldest month temperature warmer than the plantation; (b) it is possible to establish Pinus albicaulis outside of its current natural distribution at sites that have climates that are within the species' modelled historic climatic niche, although developing disease-resistant trees through selective breeding is a higher priority in the short term; (c) Abies religiosa performs well when moved $400 \mathrm{~m}$ upward in elevation and local shrubs (such as Baccharis conferta Kunth) are used as nurse plants; (d) new assisted migration field trials that contain populations from a wide range of climates tested in multiple disparate climates are needed, despite the costs; and (e) where naturalization of a migrated tree species in recipient ecosystem is viewed as undesirable, the invasive potential of the tree species should be assessed prior to large scale establishment, and stands should be monitored regularly following establishment.
\end{abstract}

Keywords: provenance test; genecology; reforestation; restoration; conservation; assisted migration; climatic change

\section{Introduction}

Climate change is expected to decouple forest tree populations from the climates to which they have become locally adapted over many generations [1-4]. Local adaptation can involve critical trade-offs; frequently, populations from colder sites are more frost resistant, although they have less growth potential than populations from warmer locations that have genetically extended growing seasons [5-7], and populations from drier 
locations may be more drought resistant or tolerant $[8,9]$. Suitable climatic habitat for given biomes, tree species, and their populations is predicted to occur at more polar latitudes and higher elevations as climate change progresses [10-14]. Indeed, natural migration of some tree populations via seed dispersal to more polar latitudes and higher elevations has already been observed [15-17], although this is not happening at the speed needed to keep populations coupled with the climatic habitat to which they have evolved. Such ongoing decoupling is creating increasing stress for tree populations. Perhaps most evident is drought stress, which makes trees weaker and less able to defend against insect and pest attacks [18]. This cascade of abiotic and biotic stresses is resulting in massive mortality of tree populations around the world [19-21]. The largest negative impacts will likely happen at the rear-edge (lower latitudinal, elevational, or xeric limit) of the natural distribution of each tree species [22-25].

The decoupling of forest tree populations from their suitable climatic habitat presents an evolutionary dilemma: populations must adapt or migrate; otherwise, the likely outcome is extirpation [3]. In the very short term, individual trees may tolerate climate change through phenotypic plasticity [26], for example, by reducing leaf area and growth rate to tolerate increasing temperatures and decreasing precipitation. In the long run, adaptation could involve natural selection of individuals more tolerant of new stresses and evolutionary rescue, when genetic adaptation allows a population to recover from demographic effects initiated by environmental change that would otherwise cause extirpation [27]. Natural populations of forest trees usually have high levels of within-population genetic variation, due to their generally large effective population sizes and outcrossing mating systems [28]. Consequently, in most tree species, there is a wide range of different genotypes where natural selection can act to confer more resistance or tolerance to drought stress, pest outbreaks, or high temperatures in subsequent generations. However, if adaptation does not occur quickly enough and decoupling continues for several generations, then the average fitness of individuals within the population or the size of the population may drop too low for it to recover through adaptation and evolutionary rescue [27].

Due to the high likelihood that climate change will negatively impact forest health and productivity $[13,29,30]$, assisted migration - the human assisted relocation of genotypes through reforestation and restoration intended to mitigate future impacts of climate change on forest health and productivity - is a climate change adaptation strategy that warrants critical examination.

Even the most critical views against assisted migration concede that more field experimental evidence of assisted migration is needed [31]. We agree that the risks and benefits of assisted migration need to be informed with more experimental evidence, particularly with well-designed provenance trials. Here, we present three case studies of field experiments established to evaluate assisted migration in forest trees. Two of these studies pertain to tree species of conservation concern (Pinus albicaulis (whitebark pine) in Canada and Abies religiosa (Sacred fir) in Mexico) and the other deal with economically important tree species (Picea glauca $\times$ engelmannii hybrid complex known as interior spruce, in Canada). These examples were selected as examples of assisted migration both within and outside the species' native geographic range. These field tests were designed expressly as tests of assisted migration, with the experimental design intended to assess the growth and survival of seed sources from climates (in general) warmer than the planting site. The detailed results of each of these case studies have already been published or are in preparation and are summarized here to provide examples of a range of experimental approaches and results, with the hopes of encouraging similar experiments with additional tree species globally.

The aim of this paper is to summarize and discuss what we have learned, including limitations and challenges to the establishment and maintenance of the field tests, based on cases that we consider illustrative from Canada and México, in order to document our current understanding and identify past pitfalls and future research priorities for new assisted migration experiments. 


\section{Key Assisted Migration Definitions}

Assisted migration (AM), as an "umbrella" term, has several different names, some of which have different meanings, but all of which refer to the translocation of individuals in anticipation of or in response to environmental change. General terms include managed relocation, managed translocation, and conservation translocation [32]. Terminology varies somewhat between fields, whether for commercial forestry management, ecological restoration, or endangered species conservation [33-45]. For the purpose of our discussion, we consider that in a forestry or tree species conservation context, assisted migration is usually considered to involve planting tree seeds from sources with climates that are slightly warmer than that of the planting site. By nudging tree populations in the direction of climate change, assisted migration is expected to help maintain forest health and productivity by restoring populations to climates where they are best adapted [37,46-48].

Assisted migration in general can be categorized into two forms (after Peterson StLaurent et al. [49]):

(a) Assisted migration within current geographic range, for simplicity referred to herein as assisted migration within range, when it involves the movement of populations within a species' current natural distribution. It has also been referred to as assisted gene flow [40] or assisted population migration [37].

(b) Assisted migration outside of current geographic range, referred herein as assisted migration outside of range, when it involves the movement of populations to locations just beyond a species' current distribution. This form of assisted migration has also been called assisted colonization [50] or assisted range expansion [37].

A third form of assisted migration, exotic translocation, involves long distance movement (sometimes trans-continental) of a population or species to locations where it is not likely to migrate naturally within the foreseeable future [37]. While intensive plantation forestry in many parts of the world is focused on non-native species (e.g., pines in the southern hemisphere), there is little demand for exotic translocations in North America because of the large number of tree species in most locations, particularly in biodiverse regions of Mexico. Consequently, we have few data upon which to evaluate long distance transfers and will not address this topic further in this report.

While assisted migration outside of range may be the form of assisted migration most commonly considered by the general public, and indeed by many forest scientists and foresters, the wide natural distribution of most North American tree species combined with the relatively short geographic and climate distances actually proposed for assisted migration [51] suggest that most AM in forestry will likely take the form of assisted migration within range.

\section{Field Tests Examined}

\subsection{Canada. Pinus albicaulis}

Materials and Climate Data

Pinus albicaulis (whitebark pine) is a high-elevation species foundational to treeline ecosystems in mountainous areas of western Canada and the United States. It has been listed as endangered under Canada's Species at Risk Act as populations are in steep decline over much of its range, primarily due to the introduced pathogen causing white pine blister rust (Cronartium ribicola), but also from mountain pine beetle (Dendroctonus ponderosae), fire suppression, and climate change. A species distribution model (SDM) projected a loss of climatically favorable habitat over most of its range in the USA under future climate scenarios [52]. A separate SDM also identified potential climate refugia in northwestern British Columbia (BC) outside of the current species range that already have contemporary climates suitable for this species and are projected to remain favorable to the end of this century (Figure 1) [53]. The apparent underfilling of the potential contemporary range of this species is typical of many North American tree species [54]. A field experiment was initiated in 2007 to (1) test the climate suitability projections of the latter model, and (2) 
evaluate the potential for assisted migration to establish populations of this species outside of the current range in areas predicted to be habitable [53].

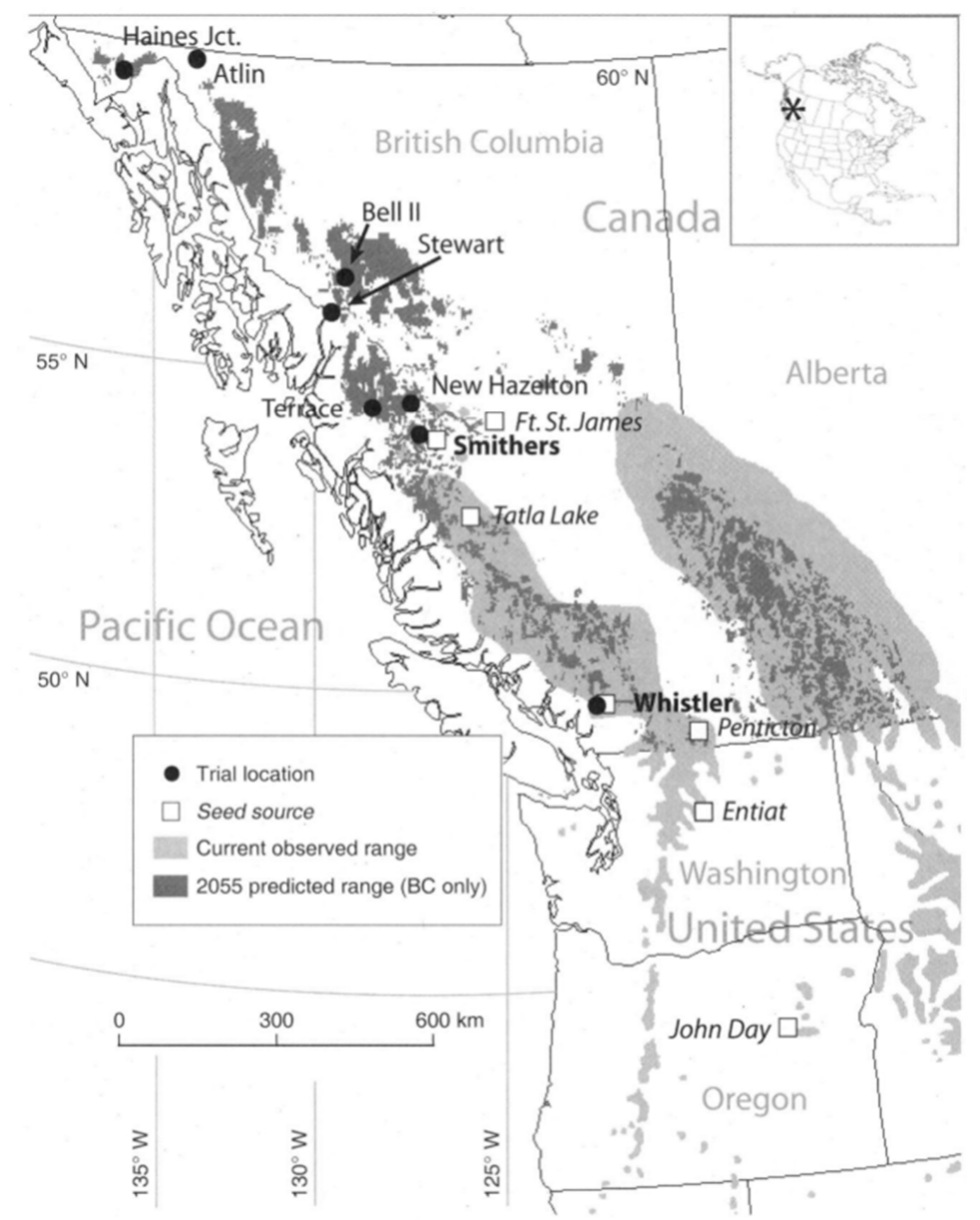

Figure 1. Location of Pinus albicaulis provenances and common garden locations for the assisted migration experiment, with current and 2055 predicted Pinus albicaulis ranges shown (from [53]).

Briefly, seed from six provenances of Pinus albicaulis was directly sown into common gardens in eight subalpine locations in $\mathrm{BC}$, including sites within the current species range, sites north of the range predicted to be climatically suitable in 2055, and sites north of the species range predicted to be unsuitable in 2055 (Figure 1). Seeds rather than seedlings were sown to test whether sites were within the species ecological niche without circumventing life history stages. Half the seeds planted were extracted from cones and sown in fall 2007, untreated, while half were subject to a maturation and dormancy-breaking treatment, then sown in the spring of 2008. Data on seedling germination, survival, and growth were collected in 2008, 2009, 2010 (see [53]), and in 2017 (Reid, McLane, Chourmouzis and Aitken, in prep.). iButton temperature recorders were placed at the soil surface at each common garden location and provided records of air temperatures in the absence of snow, as well as duration of snowpack. In alpine treeline environments, microclimate varies greatly with microsite, so data regarding slope, soil depth and type, and surrounding vegetation were collected at each common garden location. Multinomial logistic models were used to analyze germination and survival data, while general linear models were used to analyze growth data. Predictor variables tested in models included provenance climate estimates for temperature and precipitation (obtained from ClimateBC), temperatures and snowmelt dates at common garden sites (from iButtons), and planting microsite characteristics. 


\subsection{Canada. Picea glauca $\times$ engelmannii Hybrid Complex (Interior Spruce)}

Materials and Climate Data

As Picea glauca (Moench) Voss, Picea engelmannii Parry ex Engelm., and their hybrids (known locally as interior spruce, but herein referred to as Picea glauca $\times$ engelmannii) are among the most ecologically and economically important species in $\mathrm{BC}$ and throughout Canada [55], a large, long-term field provenance trial of Picea glauca $\times$ engelmannii was established by the BC government in 2005. The trial consisted of 128 natural stand populations and orchard seedlots from Canada and USA planted at each of 17 sites in BC, Yukon, and Alberta. Details regarding the populations, test sites and experimental design can be found in O'Neill et al. [56] (Figure 2).

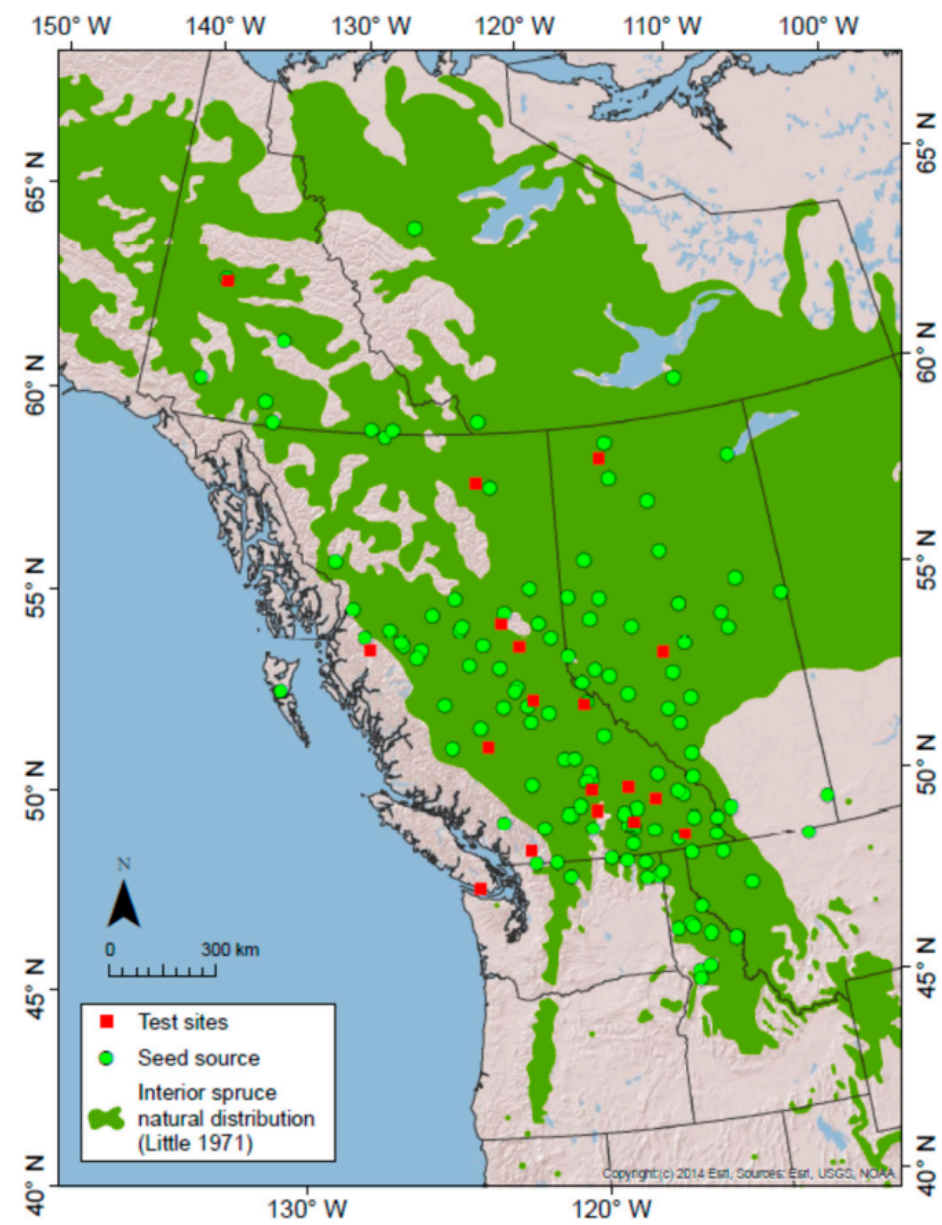

Figure 2. Seed source and test site locations used in the Picea glauca $\times$ engelmannii provenance trial. The High Level test site is located in northwest Alberta.

Height and survival were assessed at the end of the 10th field season. At each site, a productivity index (PI10) was obtained for each of the 97 natural stand populations by multiplying population mean height by population survival proportion. Values of mean coldest month temperature (MCMT) for the 1961-1990 period (hereafter referred to by its center year, 1975) were obtained for each provenance and test site from ClimateBC or ClimateNA (http:/ / climatebc.ca/) version 6.22 [57]. Mean coldest month temperature was selected because it is frequently identified as being among the most important of climate variables in accounting for population differentiation in Picea glauca $\times$ engelmannii [51] and other North American temperate conifer species [58,59].

A universal transfer function (UTF), which predicts the productivity of any population at any location, was developed following methods of $\mathrm{O}^{\prime}$ Neill et al. (2008; Appendix A). Individual transfer functions were first fitted to each site by relating population PI10 to 
population MCMT_tx (MCMT of the test site minus MCMT of the seed source) using a Cauchy function. Linear and quadratic relationships were then developed between the fitted coefficients and test site MCMT. Fitting of peaked transfer functions at the warmest and coldest sites was facilitated by the imputation of a single warm and cold anchor point population using an approach similar to that of Wang et al. [46]. Likewise, fitting of the scale parameter was enabled by the imputation of a single warm ghost test site using an approach similar to that of Rehfeldt, Leites, Joyce and Weiskittel [7]. For details of the imputation procedures see the Appendix A.

The impact of assisted migration was assessed in two ways. First, the climate of the vertex of each individual transfer function (i.e., the climate of the population expected to have the greatest productivity) was determined at each site. Second, fitted equations for the three Cauchy function parameters were substituted back into the transfer function, and response functions were estimated for a "local" population from MCMT $=-18{ }^{\circ} \mathrm{C}$, and a "migrated" population from $\mathrm{MCMT}=-15^{\circ} \mathrm{C}$, representing climates of northern and central $\mathrm{BC}$, respectively. As response functions illustrate population productivity across a range of climates, responses of alternative seed sources over time can be compared to assess their relative merit over time when planted in a common climate.

\subsection{México. Abies religiosa (Sacred Fir, Oyamel)}

Abies religiosa (Sacred fir, oyamel) forms a high altitude (mostly 2800 to $3500 \mathrm{~m}$ ), dense, shade-tolerant, moist, temperate forest in the Trans-Mexican Volcanic Belt, an east-west mountain chain containing the highest elevations in Mexico, between 19 and $20^{\circ} \mathrm{N}$ latitude [60-62], on which eastern migrating populations of monarch butterfly exclusively overwinter [63]. Some stands of this species have been severely fragmented due to their proximity to large urban areas [64]. Two high-elevation field provenance tests of Abies religiosa were established inside the core zone of the Monarch Butterfly Biosphere Reserve in México State to assess assisted migration. Specifically, the adaptation of populations from an elevation transect from the lowest to the highest elevational limit of the natural distribution of the species in the region was tested at the two high-elevation test sites. Ten populations represented by 2 year-old seedlings originating from seed collected between 3000 and $3450 \mathrm{~m}$ were planted in 2015 at Las Palomas (3440 m). Similarly, in 2017, six populations of 2 year-old seedlings originating from seed collected between 2960 and $3450 \mathrm{~m}$ were planted at Los Ailes $(3360 \mathrm{~m})$. Due to the extreme solar radiation and the large differences between day and night temperatures at these elevations, the effect of nurse plant cover provided by pre-existing natural shrubs (mostly Baccharis conferta) on survival and growth of the planted Abies religiosa seedlings was also assessed. Survival and growth were assessed for 3.5 and 1.5 years at Las Palomas and Los Ailes, respectively, providing results for 5.5 and 3.5 year-old seedlings (from germination), respectively [65].

\section{Lessons}

4.1. Pinus albicaulis Can Be Migrated North of Its Current Species Distribution in Canada within the Predicted Climatic Niche If Adequate Snowpack Is Present

Germination and 9 or 10 year survival of seedlings varied greatly among sites. Establishment from seed was expected to be low relative to seedlings as seed germination is often poor for Pinus albicaulis, because seeds of this species are eaten by many rodents and birds. In 2017, 7.4\% of all seeds produced seedlings that survived. Survival was highest at the northernmost site within the species range (Smithers, BC, Canada), at the southernmost site outside of the species range (Hazelton, BC, Canada), and surprisingly, at the northernmost site (Haines, BC, Canada), approximately $600 \mathrm{~km}$ north of the species current distribution limit near the Yukon border. Germination rates varied with population but were more a function of environmental effects on seed maturation and condition at the time of harvest than genetic differences among populations. Early results in 2009 and 2010 showed that pre-treated seeds germinated faster and at higher rates than untreated seeds, but this advantage had disappeared by 2017. In the longer term, while most untreated 
seeds had germination delayed by a year while they completed maturation in the soil, a characteristic of Pinus albicaulis, they were better synchronized with site seasonality than treated seeds. Treated seeds germinated immediately following planting regardless of site conditions and suffered greater mortality post-germination. Snow cover and snow-melt timing played a key role in average seedling survival. Sites with little or no protective snow cover in winter and those with deep snowpacks that melted late in the year both had poorer survival than those on sites with continuous snowpacks in winter that melted in April or May.

Pinus albicaulis is an extremely slow-growing species. Average height of living seedlings after eight (untreated seeds) or nine years (treated seeds) was less than $20 \mathrm{~cm}$, although individual seedlings varied greatly in height. Seedlings at the northernmost site (Haines) were approximately twice as tall as seedlings at all other sites, on average, indicating that latitude per se is not critical to the species' ecological niche, but rather, temperature and snowpack play critical roles. While this site is far north, it is not far from the Pacific Coast, and has intermediate snowfall (equivalent to $1020 \mathrm{~mm}$ of rain), relatively mild temperatures $\left(0.4{ }^{\circ} \mathrm{C}\right.$ mean annual temperature), and the warmest average summer temperature of all common garden sites [53]. These results collectively suggest that Pinus albicaulis could be migrated to climatically favourable sites well north of its current species distribution. These are likely areas of colonization debt, i.e., post-glacial migration has been too slow to fill the available niche. If seedlings rather than seeds were used to nucleate conservation populations, the survival rate would likely be higher than the current study.

\subsection{Picea glauca $\times$ engelmannii Hybrid Complex}

Negative impacts of climate change on plantation productivity may be mitigated by planting seed sources from locations that are $3{ }^{\circ} \mathrm{C}$ MCMT warmer than the plantation.

The potential benefit of assisted migration is illustrated in the interior spruce genecology function for the test site at High Level, Alberta, where the most productive populations are those that originate from locations having a MCMT approximately $3^{\circ} \mathrm{C}$ warmer than the plantation (i.e., populations that have been transferred coldward $3{ }^{\circ} \mathrm{C}$ MCMT) (Figure 3 ). The strong relationship between productivity and seed source climate at this site and others provides convincing evidence of the degree to which evolution has molded populations to be locally adapted.

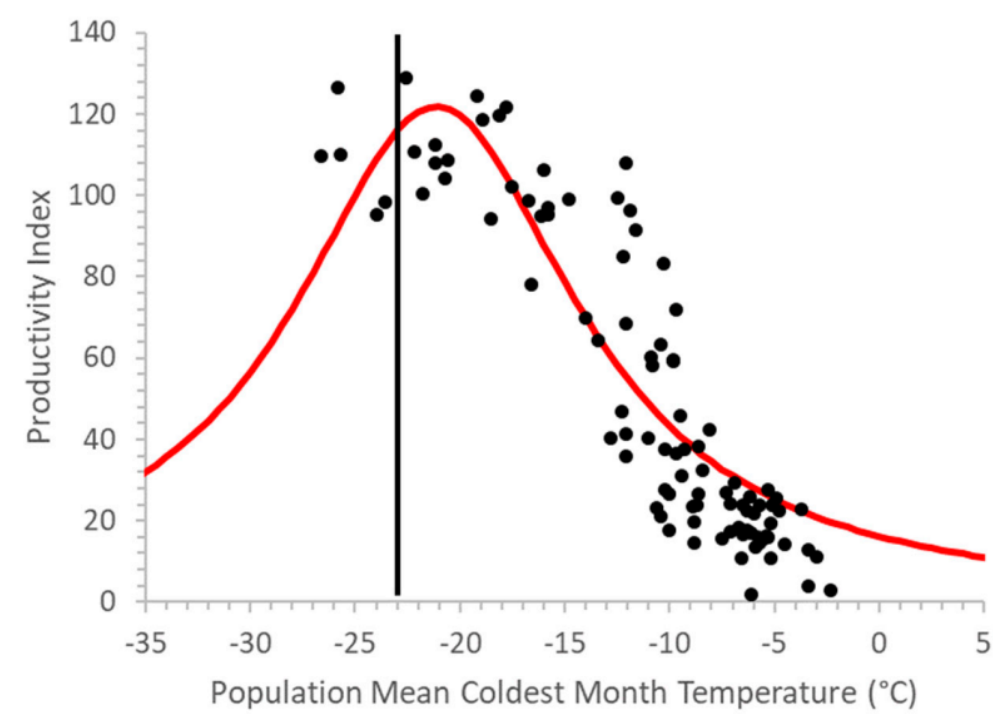

Figure 3. Genecology function for a provenance test site near the town of High Level, Alberta, showing that the most productive populations at the High Level site are those that originate from locations having a mean coldest month temperature (MCMT) approximately $3^{\circ} \mathrm{C}$ warmer than the plantation. The vertical bar identifies the MCMT of High Level, Alberta $\left(-23^{\circ} \mathrm{C}\right)$. 
Comparisons of the modelled trajectories of population productivity over time show that productivity is slightly greater for the local than the migrated population at establishment (i.e., when plantation $\mathrm{MCMT}=-18^{\circ} \mathrm{C}$ ); however, shortly after establishment (i.e., when plantation $\mathrm{MCMT} \approx-15^{\circ} \mathrm{C}$ ), the relative productivity of the migrated population surpasses that of the local population, suggesting that assisted migration can help mitigate climate change impacts to productivity (Figure 4). Where forest productivity is low or long-lived plantations are desired (as in many conservation situations), the increasing advantage of migrated populations over time can be particularly valuable.

These analyses corroborate a growing body of literature suggesting that assisted migration can help forestall some of the negative impacts of climate change on forest productivity [47,59]. In lodgepole pine (Pinus contorta), where the results of long-term provenance trials have been widely examined, assisted migration is also expected to have a positive impact on productivity [46].

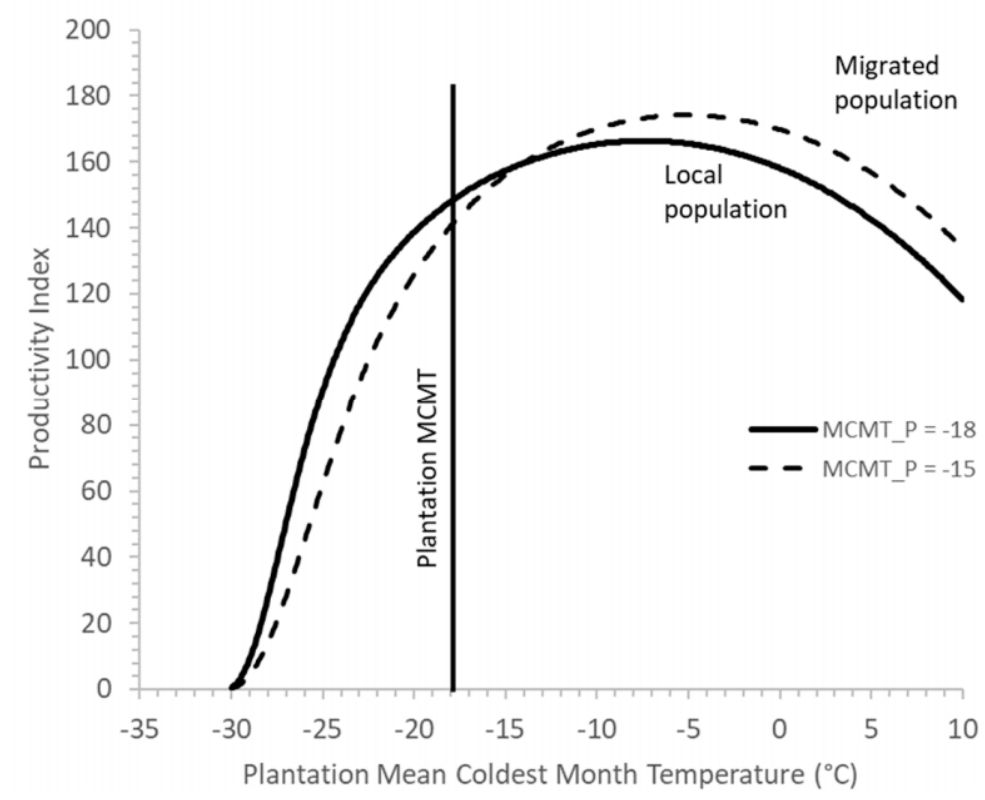

Figure 4. Modelled response function showing predicted relative productivity trajectory of "local" (solid line) and migrated (broken line) populations of Picea glauca $\times$ engelmannii hybrid complex (MCMT_P $=-18$ and $-15{ }^{\circ} \mathrm{C}$, respectively) when planted at the climate origin of the local population, represented by the vertical bar.

4.3. México. Abies religiosa. The Species Performs Well When Moved $400 \mathrm{~m}$ Upward and Local Shrubs Are Used as Nurse Plants

Upward transfer of seed sources by up to $400 \mathrm{~m}$ (equivalent to planting at a site $2{ }^{\circ} \mathrm{C}$ mean annual temperature colder than the seed source, given a lapse rate of $0.5^{\circ} \mathrm{C} / 100 \mathrm{~m}$ elevation [66]) does not appear to have any negative impacts on the planted seedlings if the seedlings are planted under the shade of local shrubs serving as nurse plants. When planted under nurse plants, survival was $83 \%$ averaged across sites and provenances; when planted outside the nurse plant crown, average survival was only $14 \%$. Thus, at least for the case of this shade-tolerant Abies religiosa species, assisted migration must be protected assisted migration, by using nurse plants as a companion for the target migrated species [65]. This finding is consistent with that of St. Clair, Howe, and Kling [59] who found that Douglas-fir seed sources moved to sites $2{ }^{\circ} \mathrm{C}$ cooler than their origin still retained acceptable long-term survival and productivity. 


\section{Limitations}

\subsection{Canada. Pinus albicaulis}

There are a number of limitations to implementing an operational assisted migration program for Pinus albicaulis. First, the major immediate challenge to this species is the pathogen Cronartium ribicola, which causes white pine blister rust. Genetic variation in rust resistance exists within this species, and there are numerous efforts underway to select for disease resistance and generate resistant seed for restoration. If this species is to be migrated, it makes sense to do this with rust resistant material as the disease will likely follow the species north. Current resources are probably best allocated to testing for disease resistance rather than assisted migration.

Secondly, Pinus albicaulis seeds are dispersed almost solely by the Clark's nutcracker (Nucifraga columbiana), a corvid that tears the non-dehiscent cones open and disperses the seeds into soil caches. If Pinus albicaulis populations are established farther north, well outside of the native range of this bird species, will the birds follow? If not, then migrated tree populations will not likely naturalize.

Finally, the assisted migration of this species is to a large extent an ethical issue and will require careful societal consideration of issues beyond biology. In BC, public support for assisted migration within species range is considerably higher than support for movements outside the current range [67]. In addition, opportunities to conserve this species and genetic diversity in climatic refugia within the existing species range should be acted upon [68]. Palmer and Larson [69] analyzed the ethics of Pinus albicaulis assisted migration and concluded that, on balance, there appear to be good reasons to justify moving this species. Pinus albicaulis enthusiasts may welcome this practice to increase the survival of this charismatic species. However, local people including indigenous communities who relate to subalpine and alpine ecosystems in recipient areas as they are today may resist the introduction of non-local species into those ecosystems, and such societal concerns might apply to other species. In fact, one indigenous community expressed opposition to this experiment at the time of establishment for this reason.

\subsection{Canada. Picea glauca $\times$ engelmannii Hybrid Complex}

The Picea glauca $\times$ engelmannii provenance trial contains one of the widest ranges of population and test site climates in North America, so one may expect a high likelihood of observing local adaptation at these sites. Nonetheless, transfer functions were nearly flat at almost half of the test sites at age six [56], suggesting (at those sites) that the species complex lacks local adaptation. Further, where local adaptation was observed, it varied widely, and was only weakly related to site climate. Sites that did not display strong local adaptation may have escaped extreme climate events or biotic agents or may have lacked local soil edaphic conditions needed to reveal local adaptation (i.e., needed to translate genetic differences among populations into phenotypic differences) [70]. Older tests or different test site locations may have resulted in stronger evidence of local adaptation or more test sites showing local adaptation. Therefore, when developing BC's climatebased seed transfer system, its designers chose to err on the side of caution by including data from only those sites having the steepest transfer functions where local adaptation was strongest [48].

\section{How Far Is Too Far? Determining a Suitable Migration Distance}

The climate distance populations are migrated in assisted migration initiatives (i.e., the migration distance) that can significantly impact the success of those efforts; migration distances that are too short may be ineffective, while those that are too long may result in early mortality due to cold injury. Comparisons of modelled response functions for populations from a range of climates can help identify optimum migration distances by identifying seed source climates expected to maximize productivity over the expected lifetime of the plantation ([47]; see also Picea glauca $\times$ engelmannii example, Figure 4). 
Nonetheless, establishing plantations with seed sources whose 1940s climate matches a plantation's current climate would address any adaptation lag that has arisen since the onset of rapid anthropogenic climate warming in the 1950s. However, accounting solely for anthropogenic climate change by attempting to optimize adaptation at establishment could compromise adaptation in later decades, given continued climate change, especially for long-lived species. Therefore, the optimum migration distance should also consider climate change during the lifespan of a plantation by weighing the risk of maladaptation during seedling establishment with the risk of maladaptation towards the end of a plantation's lifespan [51]. A recently implemented assisted migration system in BC adopted the projected climate at one quarter of the plantation's expected lifespan as the adaptation target date [48].

The logic employed in this proposal is not a radical or risky departure from previous seed sourcing practices, as it attempts to re-establish pre-existing genotype-climate relationships and does not depend on projections of the late 21st century climate. Arguably, the migration distance calculation proposed here, being dependent on only the 1931-1960 climate mean of the seed source and the projected plantation climate of approximately 2040 , is less prone to error than migration distances interpreted from adaptation lags shown in transfer functions (Figure 3 ) or by comparison of modelled response functions for populations from a range of climates (Figure 4), which can vary considerably with transfer range, model function, tree age, and different dependent and independent variables.

\subsection{México. Abies religiosa. Too Short Observational Period}

Due to the young ages of the field trials, interannual climatic variability may not have been fully represented, and population differentiation may not be fully expressed. Although the Las Palomas test site experienced an historic extreme winter storm resulting in the windfall of about 25,000 trees in a single night [65,71], during the observation period, there were no extreme heat waves or droughts that might have caused mortality. The short period of observation is directly linked to budget limitations.

\section{Challenges}

\subsection{Making Large Multisite Provenance Field Trials More Affordable}

Provenance tests were first used to identify superior seed sources for reforestation, and subsequently, to quantify safe seed transfer distance [72]. New analytical approaches have extended their application by providing estimates of impacts of seed transfer [73] and climate change $[34,46,74-77]$ on the growth and survival of tree populations. However, few older multisite provenance trials contain a sufficiently wide climate range among populations or sites to allow accurate estimation of seed transfer or climate change impacts [3]. Examples of trials containing wide population or site sampling include Quercus petraea in the European Union [78]; Pinus sylvestris in Scandinavia [79]; the Assisted Migration Adaptation Trial in Canada and the USA [80]; and trials of Pinus sylvestris in the former Soviet Union [81-83].

Remarkably few older provenance trials contain test sites located outside the contemporary species distribution $[78,84]$, limiting the ability to assess assisted migration outside of range. Further, costs of provenance trials can be prohibitive where numerous tree species are planted, or unjustifiable where few seedlings are planted. Nonetheless, collaboration among jurisdictions (provinces, states, and countries) can reduce costs to individual jurisdictions, while increasing the climate range of test populations and sites [84], arguably the most significant limitation of early provenance trials. Careful selection of populations (i.e., sampling widely and uniformly across climates) could reduce numbers of populations needed in future trials. Additionally, careful blocking, incomplete block alpha-design [85], and use of single-tree plots can reduce the number of seedlings needed for each population to have adequate statistical power to characterize patterns of adaptive variation. More strategic selection of populations and test sites using geographic information systems and climate models, sampling a wider climate range, and careful prioritization of species to 
be tested could reduce costs while increasing effectiveness [34]. Demonstration of similar climate clines for adaptation traits among a wide range of tree species mitigates the need for provenance trials for all species $[6,86]$.

\subsection{Replications over Time}

As seedlings are perhaps the most vulnerable life stage, it would be ideal to replicate field experiments across several years, in order to capture effects of interannual variation on survival at early ages. Both longer periods of observation and among-year replications of experiments can be difficult to achieve due to the short-term nature of research funding, and an overall lack of funding, particularly for México.

\subsection{The Dilemma of Species Prioritization in Megabiodiverse Countries}

Given many tree species and limited resources, it is challenging to prioritize species for assisted migration research, either for conservation or for wood production objectives. This is particularly the case in México, a country with incredible biodiversity and very limited funding. Given the shortage of funding, and the need to test many species, how should priorities be set for assisted migration research? We suggest that priority should be granted first to species having a high risk of extirpation in the short term (e.g., Mexican spruces: Picea chihuahuana, P. martinezii and P. mexicana; see [50]). The second priority should go to species of the highest economic potential (e.g., Pinus patula and Pinus pseudostrobus). These experiments would provide the basis for adaptative management strategies needed to address climate change, particularly in those human communities that depend on sustainable forest management, for example, the indigenous communities of Nuevo San Juan Parangaricutiro and Cherán, of the Purhépecha ethnic group that manage Pinus pseudostrobus, at Michoacán state, in central-western México and the Ixtlán de Juárez, Oaxaca, Southern México, Zapoteco ethnic group that manage Pinus patula. The third high-priority group should be species that have the highest ecological and biological conservation values (e.g., Abies religiosa for establishing and conserving climate-resilient monarch butterfly overwintering sites).

\subsection{When Poleward Migration Is Not an Option}

The primary geographic direction of migration will vary among species and with local topography. In the case of Abies religiosa, the upper altitudinal limit of the natural distribution of the species approximately coincides with the summits of the Monarch Butterfly Biosphere Reserve (MBBR), between 3550 and $3600 \mathrm{~m}$. It may not be possible to establish $A$. religiosa populations beyond the contemporary upper altitudinal limit inside the MBBR. An option would be to conduct assisted migration outside of range of $A$. religiosa at altitudes above $3600 \mathrm{~m}$, on higher altitude mountains, such as extinct volcanoes along the Mexican Transvolcanic Belt: Nevado de Toluca, Popocatépetl, Iztachíhuatl, La Malinche, Cofre de Perote and Pico de Orizaba [87]. A. religiosa at present is also distributed on each of these mountains, but also with an upper elevation limit between 3550 and $3600 \mathrm{~m}$. The challenge, then, would be to establish $A$. religiosa populations, for example, between 3800 and $4000 \mathrm{~m}$ on any of those mountains, as potential future sites for monarch butterfly overwintering sites. The task would not be easy, because at 3800 to $4000 \mathrm{~m}$, the vegetation is largely alpine grassland (e.g., Muhlenbergia macroura with low density of Pinus hartwegii), where the extreme low temperatures make the environment quite harsh. Thus, the use of nurse plants to establish assisted migration tests at those altitudes would be needed. That of course assumes that monarch butterflies would be able to locate these afforested A. religiosa stands and have sufficient plasticity to overwinter at these sites.

\subsection{Tackling Uncertainty by Promoting Genetic Diversification}

While assisted migration has received significant attention as a climate change adaptation strategy [88,89], diversification of forestry practices (e.g., use of alternative silviculture systems, planting more tree species, prioritizing harvest in areas of high risk of distur- 
bance) and genetic diversification in particular have also been proposed to buffer some of the uncertainty in climate change projections $[1,31,90]$. Crop diversification is commonly practiced by farmers to mitigate uncertainty associated with crop prices and variability in production due to pest outbreaks and extreme weather [91], and portfolio diversification is widely used by investors to stabilize returns from fluctuating markets [92]. To the extent that populations differ in adaptation, they will differ in their capacity to tolerate disturbances, including climate extremes. The need for genetic diversity in reforestation materials has been examined [93] and standards are in place in many jurisdictions [94]. Greater genetic diversity could be achieved in plantation forestry by planting multiple seedlots from different climates, or by increasing effective population size in orchard or natural stand seed collections [95]. Borrowing from economic theory, Crowe and Parker [96] proposed a robust climate change adaptation strategy in which the selection of genetic material (sets of genotypes) to be used in reforestation is optimally adapted to multiple, equally probable future climates. Importantly, genetic diversification and assisted migration are independent strategies, they can be used separately or jointly. Nonetheless, while provenance trials can provide strong support for assisted migration, and guidelines for assisted migration (i.e., migration distance) have been presented in this report and elsewhere [48,51], few trials or specific guidelines exist for genetic diversification as a climate change adaptation strategy (but see [31]).

\section{Mitigating Risks}

\subsection{Introduction of Species That Might Become Invasive}

Several concerns have been raised regarding assisted migration within range and, in particular, assisted migration outside of range [67]. The most frequent concern [38] pertains to assisted migration outside of range disrupting or displacing local ecological communities and that relocated populations could become invasive [97,98]. An assessment of the relationship between distance from source to introduction site and invasiveness by Mueller and Hellmann [99] concluded that while the proportion of species migrated within regions of continents that becomes invasive is relatively small, the impacts of those invasions can be large. Therefore, invasiveness needs to be addressed as part of assisted migration outside of range programs, through assessment of risks before translocations, and monitoring during and after implementation. Before implementing a program of assisted migration outside of range, it might be useful to consider if the species has weedy characteristics (e.g., high fecundity, early age of reproduction, wide soil type tolerance) or close relatives that have shown invasive behavior. Considering that assisted migration outside of range in forestry will mostly be aimed at woody species, Daehler [100] concluded through a taxonomic analysis that nitrogen-fixers and clonal trees show the highest risk of becoming natural area invaders, along with species that are primarily aquatic or semiaquatic, and grasses. Therefore, special attention should be taken when considering assisted migration outside of range with these types of species.

During and after implementation of a program of operational assisted migration outside of range, population health and naturalization of the planted materials should be monitored regularly. Introduced species may show no invasive behavior for decades after planting, due to lags in reproduction and establishment, and then spread rapidly, a particular concern for invasion biology [101-103]. In the case of assisted migration outside of range, rapid spread may be considered a success since the species is being introduced intentionally or may be a concern due to ecological effects on the recipient ecosystem. How this is viewed will vary with individuals and their priorities for ecosystems.

\subsection{Mismatch of Biotic Interactions}

Concern exists that assisted migration within and outside of range may cause a mismatch in biotic interactions [31]. Empirical evidence on this issue is accumulating. Camarretta et al. [104] concluded in a study of species and provenance translocation into different community assemblages that performance was not affected by community 
context. Additionally, experimental evidence has suggested that migrating plants with the soil biota of the site of origin increases plant performance in the target site [105], and that assisted migration outside of range is possible along elevation gradients for some rare species [106]. These, and other studies, suggest that biotic interactions and the more complex set of interactions among biotic and abiotic factors will influence the outcome of assisted migration within or outside of range. More trials and close monitoring of performance are necessary to further clarify this issue for individual species as it will be difficult to generalize across species.

\subsection{Outbreeding Depression}

Genetic risks of assisted migration outside of range include outbreeding depression, disruption of local adaptation by non-climatic factors, and population replacement [40]. Outbreeding depression is only likely in wind-pollinated tree species when individuals are moved between long-diverged populations, e.g., subspecies or varieties. If outbreeding depression exists but is weak, natural selection will remove deleterious immigrant alleles over time, allowing mean fitness to recover and surpass that of the local population, according to population simulation modelling [40]. Genetic incompatibilities causing outbreeding depression are unlikely in widespread forest tree species such as those discussed here. Field trials and good knowledge of the biology and silvics of species can provide information about local adaptation to environmental factors such as soil type, pests, pathogens, or mutualists. If translocated individuals have higher fitness than the resident population, and if the population is naturally regenerating rather than being planted, over time the genetic composition of the population may gradually be replaced by the introduced genotypes. As this will increase the average fitness of the local population, this replacement is more likely a benefit than a risk.

Furthermore, to reduce ecological risks, care should be taken to avoid unintended introductions of species hitch-hiking with planted seedlings and their soil, as hitch-hikers, non-pathogenic in their native environment, may become pathogenic on naïve hosts in their new environments.

\subsection{Balancing the Risks: The Core Dilemma}

Assisted migration, in particular assisted migration outside of range, is perceived by some observers as a risky management measure, because it could cause: (a) negative interactions with other organisms of the recipient community (for example, when the translocated genotypes become invasive and displace other local plant species; [31]), and (b) outbreeding depression, disruption of local adaptation to non-climatic factors, and disruption of mutualist or parasitic relationships among species [31,40]. In our view, such risks exist to varying degrees, but need to be considered in relation to the risks of inaction, which can be dire, as numerous modelling studies have predicted $[14,50,53,58]$. What will happen to forest communities in the future if no interventions are made under different scenarios of greenhouse gas emissions, i.e., Representative Concentration Pathway (RCP) 8.5 (pessimistic) or RCP 4.5 (intermediate)? The fact is that atmospheric $\mathrm{CO}_{2}$ concentrations are currently 414 ppm (July 2020 record; https: / / www.esrl.noaa.gov/gmd/ccgg/trends/), and climate records are being broken nearly every year [107]. Additionally, a more worrisome sign is that forest decline is already well underway in many forests of the world, linked to heat waves, drought stress, and climate-associated insect and disease outbreaks [19-21,45]. For A. religiosa, for example, there is already growing evidence of the lack of regeneration at lower elevations of the species' distribution $[108,109]$. Thus, we need to avoid inaction because that might make us simply witnesses of an upcoming ecological disaster.

\section{Conclusions}

Evidence from these field tests suggests that in general, tree populations grow well when moved to planting locations 2 to $3{ }^{\circ} \mathrm{C}$ mean annual temperature colder than their 
origin. Tree species can also establish and grow well when moved outside of their natural distributions to sites with climates within their modelled historic climatic niches.

In the case of a shade-tolerant species such as Abies religiosa, the use of nurse plants may be necessary to protect the target species by ameliorating extreme temperatures, either day/night fluctuations, the coldest temperatures of winter, or the warmest temperatures during the warm, dry season (March-May in México). With the use of nurse plants, an upward shift of populations by up to $400 \mathrm{~m}$ appears to have no negative impact on growth or survival.

However, as heat waves and unusual drought periods become more frequent, prolonged, and intense, it might be advisable to use nurse plants to increase the survival of the targeted seedlings even for shade-intolerant pine species. For example, British Columbia experienced two extreme droughts during the summer of 2017 and 2018, which caused significant mortality in young plantations [110]. Whereas shade from adjacent vegetation has long been considered undesirable for shade-intolerant tree species in British Columbia, frequent, extreme droughts may require reconsideration of that view in drought-prone regions or coarse, shallow soils.

Long-term, multi-site field tests located in disparate climates are needed to develop accurate climate transfer and response functions for priority species. Collaboration among neighbouring jurisdictions and careful field test design can help reduce costs.

For some species such as Pinus albicaulis, developing disease-resistant trees through selective breeding may be a higher priority than assisted migration, and have a greater impact on tree health and population size. However, once resistant material is available, it can be integrated into a restoration program that includes assisted migration.

Planning of field provenance trials requires a long-term budget and human resource commitment. Collecting and extracting seed, producing seedlings, and locating and preparing test sites can take 5 years; an additional 10-15 years of field testing, with frequent test site maintenance, may be needed before extreme climate events and pest disturbances reveal patterns of adaptation.

Assessment of invasion risk is warranted prior to, and regular monitoring after, implementation of an assisted migration test or program, particularly for tree species having weedy traits, if naturalization of the migrated species is not desired. Careful screening for hitch-hiking pests on seedlings prior to migration out of range is also recommended.

Author Contributions: C.S.-R. and S.N.A. conceived the paper. C.S.-R., G.O. and S.N.A. provided experimental data and analysis per species. R.L.-C. developed the mitigating risk section. C.S.-R., G.O. and S.N.A. led the writing. All authors have read and agreed to the published version of the manuscript.

Funding: Funding was provided by the Coordinación de la Investigación Científica of the Universidad Michoacana de San Nicolás de Hidalgo to C.S.-R.

Acknowledgments: This paper is an undertaking of the Forest Genetic Resources Working Group/ North American Forest Commission/Food and Agricultural Organization of the United Nations. Thanks to Christine Chourmouzis for phenotyping the Pinus albicaulis experiment in 2018, and to Iain Reid for preliminary analyses of the resulting data. The Picea glauca $\times$ engelmannii provenance trial map was created by Amy Vallarino. Thanks to Barry Jaquish, co-investigator of the Picea glauca $\times$ engelmannii provenance trial.

Conflicts of Interest: The authors declare no conflict of interest.

\section{Appendix A.}

Methodological details for the analysis of Picea glauca $\times$ engelmannii hybrid complex (interior spruce) field tests.

\section{Appendix A.1. Anchor Points for P. glauca $\times$ engelmannii Analysis}

As the climate ranges of populations and test sites were mostly over-lapping, it became necessary to impute anchor points in order to develop peaked transfer functions at the 
warmest and coldest sites. Preliminary analyses identified mean coldest month temperature $\left({ }^{\circ} \mathrm{C}\right)$ transfer distance (MCMT_tx, MCMT of the test site minus MCMT of the seed source) as the transfer distance climate variable most strongly related to PI10. Therefore, the mean MCMT_tx among the $2 \%$ of population X site transfers that experienced the greatest "coldward" transfer and the $1 \%$ of population $X$ site ransfers that experienced the greatest "warmward" transfer was calculated. Estimated P110 of a "local" population (i.e., P110L, a population growing in a climate equal to its origin, that is, at MCMT_tx $=0$ ) was obtained from the preliminary analyses, and used to calculate the relative productivity index, PI10R (PI10/PI10L), of each population X site combination, from which mean PI10R of transfers in each of the two groups ( $2 \%$ coldest and $1 \%$ warmest transfers) was calculated. P110L was multiplied by mean PI10R to obtain a single PI10 anchor point value at each site.

\section{Appendix A.2. Universal Transfer Function and Ghost Test Site for P. glauca $\times$ engelmannii Analysis}

A universal transfer function (UTF), which predicts the productivity of any population at any location, was developed following methods of $\mathrm{O}^{\prime}$ Neill et al. (2008). Transfer functions were first fitted to each site by relating population PI10 to population MCMT_tx using a Cauchy function. Linear and quadratic relationships were then developed between the three coefficients and test site MCMT. Due to the lack of a test sites towards the upper thermal limit of interior spruce, it was impossible to develop a peaked function for the scale parameter A. Therefore, using an approach similar to that of Rehfeldt et al. (2017), a "ghost" point with $\mathrm{A}=0$ (all planted populations expected to die) was generated and used in fitting the scale parameter equation. The ghost point was created at MCMT $=6.8^{\circ} \mathrm{C}$ by adding $10^{\circ} \mathrm{C}$ to the warmest interior $\mathrm{BC}$ location at which interior spruce was found on the tree species layer of the provincial geospatial database.

\section{Appendix A.3. Appendix References}

O'Neill, G.A., Hamann, A., and Wang, T. 2008. Accounting for population variation improves estimates of the impact of climate change on species' growth and distribution. Journal of Applied Ecology 45: 1040-1049. http:/ / onlinelibrary.wiley.com/doi/10.1111/j. 1365-2664.2008.01472.x/full.

Rehfeldt GE, Leites LP, Joyce DG, Weiskittel AR. 2017. Role of population genetics in guiding ecological responses to climate. Global Change Biology 24:858-868.

\section{References}

1. Ledig, F.T.; Kitzmiller, J.H. Genetic strategies for reforestation in the face of global climate change. For. Ecol. Manag. 1992, 50, 153-169. [CrossRef]

2. Rehfeldt, G.E.; Wykoff, W.R.; Ying, C.C. Physiologic plasticity, evolution, and impacts of a changing climate on Pinus contorta. Clim. Chang. 2001, 50, 355-376. [CrossRef]

3. Aitken, S.N.; Yeaman, S.; Holliday, J.A.; Wang, T.; Curtis-McLane, S. Adaptation, migration or extirpation: Climate change outcomes for tree populations. Evol. Appl. 2008, 1, 95-111. [CrossRef] [PubMed]

4. Rehfeldt, G.E.; Jaquish, B.C.; López-Upton, J.; Sáenz-Romero, C.; St Clair, J.B.; Leites, L.P.; Joyce, D.G. Comparative genetic responses to climate for the varieties of Pinus ponderosa and Pseudotsuga menziesii: Realized climate niches. For. Ecol. Manag. 2014, 324, 126-137. [CrossRef]

5. Rehfeldt, G.E. Ecological genetics of Pinus contorta from the Rocky Mountains (USA): A synthesis. Silv. Genet. 1988, 37, 131-135.

6. Aitken, S.N.; Bemmels, J.B. Time to get moving: Assisted gene flow of forest trees. Evol. Appl. 2016, 9, 271-290. [CrossRef]

7. Rehfeldt, G.E.; Leites, L.P.; Joyce, D.G.; Weiskittel, A.R. Role of population genetics in guiding ecological responses to climate. Glob. Chang. Biol. 2017, 24, 858-868. [CrossRef]

8. Sáenz-Romero, C.; Guzmán-Reyna, R.R.; Rehfeldt, G.E. Altitudinal genetic variation among Pinus oocarpa populations in Michoacán, Mexico: Implications for seed zoning, conservation, tree breeding and global warming. For. Ecol. Manag. 2006, 229, 340-350. [CrossRef]

9. Alvarez-Maldini, C.; Acevedo, M.; Dumroese, R.K.; González, M.; Cartes, E. Intraspecific variation in drought response of three populations of Cryptocarya alba and Persea lingue, two native species from mediterranean central Chile. Front. Plant Sci. 2020, 11, 1-15. [CrossRef]

10. Peñuelas, J.; Ogaya, R.; Boada, M.S.; Jump, A. Migration, invasion and decline: Changes in recruitment and forest structure in a warming-linked shift of European beech forest in Catalonia (NE Spain). Ecography 2007, 30, 829-837. [CrossRef] 
11. Iverson, L.R.; Prasad, A.M.; Matthews, S.N.; Peters, M. Estimating potential habitat for 134 eastern US tree species under six climate scenarios. For. Ecol. Manag. 2008, 254, 390-406. [CrossRef]

12. Rehfeldt, G.E.; Crookston, N.L.; Sáenz-Romero, C.; Campbell, E.M. North American vegetation model for land-use planning in a changing climate: A solution to large classification problems. Ecol. Appl. 2012, 22, 119-141. [CrossRef]

13. Rehfeldt, G.E.; Jaquish, B.C.; Sáenz-Romero, C.; Joyce, D.G.; Leites, L.P.; St Clair, J.B.; López-Upton, J. Comparative genetic responses to climate in the varieties of Pinus ponderosa and Pseudotsuga menziesii: Reforestation. For. Ecol. Manag. 2014, 324, 147-157. [CrossRef]

14. Gómez-Pineda, E.; Sáenz-Romero, C.; Ortega-Rodríguez, J.M.; Blanco-García, A.; Madrigal-Sánchez, X.; Lindig-Cisneros, R.; Lopez-Toledo, L.; Pedraza-Santos, M.E.; Rehfeldt, G.E. Suitable climatic habitat changes for Mexican conifers along altitudinal gradients under climatic change scenarios. Ecol. Appl. 2020, 30, e02041. [CrossRef] [PubMed]

15. Lenoir, J.; Gégout, J.-C.; Marquet, P.; De Ruffray, P.; Brisse, H. A significant upward shift in plant species optimum elevation during the 20th century. Science 2008, 320, 1768-1771. [CrossRef] [PubMed]

16. Alfaro-Ramírez, F.U.; Arredondo-Moreno, J.T.; Pérez-Suárez, M.; Endara-Agramont, Á.R. Pinus hartwegii Lindl. treeline ecotone: Structure and altitudinal limits at Nevado de Toluca, Mexico. Rev. Chapingo. Ser. Cienc. For. Ambiente 2017, 23, 261-273. [CrossRef]

17. Trant, A.; Higgs, E.; Starzomski, B.M. A century of high elevation ecosystem change in the Canadian Rocky Mountains. Sci. Rep. 2020, 10, 1-10. [CrossRef] [PubMed]

18. Alfaro, R.I.; Fady, B.; Vendramin, G.G.; Dawson, I.K.; Fleming, R.A.; Sáenz-Romero, C.; Lindig-Cisneros, R.A.; Murdock, T.; Vinceti, B.; Navarro, C.M. The role of forest genetic resources in responding to biotic and abiotic factors in the context of anthropogenic climate change. For. Ecol. Manag. 2014, 333, 76-87. [CrossRef]

19. Allen, C.D.; Macalady, A.K.; Chenchouni, H.; Bachelet, D.; McDowell, N.; Vennetier, M.; Kitzberger, T.; Rigling, A.; Breshears, D.D.; Hogg, E.T. A global overview of drought and heat-induced tree mortality reveals emerging climate change risks for forests. For. Ecol. Manag. 2010, 259, 660-684. [CrossRef]

20. Allen, C.; Breshears, D.; McDowell, N. On underestimation of global vulnerability to tree mortality and forest die-off from hotter drought in the Anthropocene. Ecosphere 2015, 6, 1-55. [CrossRef]

21. Hogg, E.H.; Michaelian, M.; Hook, T.I.; Undershultz, M.E. Recent climatic drying leads to age-independent growth reductions of white spruce stands in western Canada. Glob. Chang. Biol. 2017, 23, 5297-5308. [CrossRef] [PubMed]

22. Hampe, A.; Petit, R.J. Conserving biodiversity under climate change: The rear edge matters. Ecol. Lett. 2005, 8, 461-467. [CrossRef] [PubMed]

23. Jump, A.S.; Hunt, J.M.; Penuelas, J. Rapid climate change-related growth decline at the southern range edge of Fagus sylvatica. Glob. Chang. Biol. 2006, 12, 2163-2174. [CrossRef]

24. Mátyás, C. Forecasts needed for retreating forests. Nature 2010, 464, 1271. [CrossRef] [PubMed]

25. Mátyás, C.; Berki, I.; Czúcz, B.; Gálos, B.; Móricz, N.; Rasztovits, E. Future of beech in Southeast Europe from the perspective of evolutionary ecology. Acta Silv. Lignaria Hung. 2010, 6, 91-110.

26. Fréjaville, T.; Fady, B.; Kremer, A.; Ducousso, A.; Benito Garzón, M. Inferring phenotypic plasticity and population responses to climate across tree species ranges using forest inventory data. Glob. Ecol. Biogeogr. 2019, 28, 1259-1271. [CrossRef]

27. Gonzalez, A.; Ronce, O.; Ferriere, R.; Hochberg, M.E. Evolutionary rescue: An emerging focus at the intersection between ecology and evolution. Philosoph. Trans. R. Soc. B 2012, 368, 1-8. [CrossRef]

28. Hamrick, J.L.; Godt, M.J.W.; Sherman-Broyles, S.L. Factors influencing levels of genetic diversity in woody plant species. New For. 1992, 6, 95-124. [CrossRef]

29. St Clair, J.B.; Howe, G.T. Genetic maladaptation of coastal Douglas-fir seedlings to future climates. Glob. Chang. Biol. 2007, 13, 1441-1454. [CrossRef]

30. Michaelian, M.; Hogg, E.H.; Hall, R.J.; Arsenault, E. Massive mortality of aspen following severe drought along the southern edge of the Canadian boreal forest. Glob. Chang. Biol. 2011, 17, 2084-2094. [CrossRef]

31. Bucharova, A. Assisted migration within species range ignores biotic interactions and lacks evidence. Restorat. Ecol. 2017, 25, 14-18. [CrossRef]

32. Richardson, D.M.; Hellmann, J.J.; McLachlan, J.S.; Sax, D.F.; Schwartz, M.W.; Gonzalez, P.; Brennan, E.J.; Camacho, A.; Root, T.L.; Sala, O.E. Multidimensional evaluation of managed relocation. Proc. Natl. Acad. Sci. USA 2009, 106, 9721-9724. [CrossRef] [PubMed]

33. McLachlan, J.S.; Hellmann, J.J.; Schwartz, M.W. A framework for debate of assisted migration in an era of climate change. Conserv. Biol. 2007, 21, 297-302. [CrossRef] [PubMed]

34. Wang, T.; O'Neill, G.A.; Aitken, S.N. Integrating environmental and genetic effects to predict responses of tree populations to climate. Ecol. Appl. 2010, 20, 153-163. [CrossRef] [PubMed]

35. Gray, L.K.; Gylander, T.; Mbogga, M.S.; Chen, P.-y.; Hamann, A. Assisted migration to address climate change: Recommendations for aspen reforestation in western Canada. Ecol. Appl. 2011, 21, 1591-1603. [CrossRef] [PubMed]

36. Gray, L.K.; Hamann, A. Strategies for reforestation under uncertain future climates: Guidelines for Alberta, Canada. PLoS ONE 2011, 6, e22977. [CrossRef]

37. Leech, S.M.; Almuedo, P.L.; O’Neill, G. Assisted migration: Adapting forest management to a changing climate. J. Ecosyst. Manag. 2011, 12, 18-34. Available online: http://jem.forrex.org/index.php/jem/article/view/91/98 (accessed on 15 November 2020). 
38. Hewitt, N.; Klenk, N.; Smith, A.L.; Bazely, D.R.; Yan, N.; Wood, S.; MacLellan, J.I.; Lipsig-Mumme, C.; Henriques, I. Taking stock of the assisted migration debate. Biol. Conserv. 2011, 144, 2560-2572. [CrossRef]

39. Pedlar, J.H.; McKenney, D.W.; Aubin, I.; Beardmore, T.; Beaulieu, J.; Iverson, L.; O’Neill, G.A.; Winder, R.S.; Ste-Marie, C. Placing forestry in the assisted migration debate. BioScience 2012, 62, 835-842. [CrossRef]

40. Aitken, S.N.; Whitlock, M.C. Assisted gene flow to facilitate local adaptation to climate change. Annu. Rev. Ecol. Evol. Syst. 2013, 44, 367-388. [CrossRef]

41. Lu, P.; Parker, W.H.; Cherry, M.; Colombo, S.; Parker, W.C.; Man, R.; Roubal, N. Survival and growth patterns of white spruce (Picea glauca [M oench] Voss) rangewide provenances and their implications for climate change adaptation. Ecol. Evol. 2014, 4, 2360-2374. [CrossRef] [PubMed]

42. McKenney, D.W.; Pedlar, J.H.; Lawrence, K.; Papadopol, P.; Campbell, K.; Hutchinson, M.F. Change and evolution in the plant hardiness zones of Canada. BioScience 2014, 64, 341-350. [CrossRef]

43. Castellanos-Acuña, D.; Lindig-Cisneros, R.; Sáenz-Romero, C. Altitudinal assisted migration of Mexican pines as an adaptation to climate change. Ecosphere 2015, 6, 1-16. [CrossRef]

44. Koralewski, T.E.; Wang, H.-H.; Grant, W.E.; Byram, T.D. Plants on the move: Assisted migration of forest trees in the face of climate change. For. Ecol. Manag. 2015, 344, 30-37. [CrossRef]

45. Sáenz-Romero, C.; Mendoza-Maya, E.; Gómez-Pineda, E.; Blanco-García, A.; Endara-Agramont, A.R.; Lindig-Cisneros, R.; López-Upton, J.; Trejo-Ramírez, O.; Wehenkel, C.; Cibrián-Tovar, D. Recent evidence of Mexican temperate forest decline and the need for ex situ conservation, assisted migration, and translocation of species ensembles as adaptive management to face projected climatic change impacts in a megadiverse country. Can. J. For. Res. 2020, 50, 843-854. [CrossRef]

46. Wang, T.; Hamann, A.; Yanchuk, A.; O'neill, G.; Aitken, S. Use of response functions in selecting lodgepole pine populations for future climates. Glob. Chang. Biol. 2006, 12, 2404-2416. [CrossRef]

47. Nigh, G. Mitigating the effects of climate change on lodgepole pine site height in British Columbia, Canada, with a transfer function. For. Int. J. For. Res. 2014, 87, 377-387. [CrossRef]

48. O’Neill, G.; Wang, T.; Ukrainetz, N.; Charleson, L.; McAuley, L.; Yanchuk, A.; Zedel, S. A Proposed Climate-Based Seed Transfer System for British Columbia; Technical Report 099; Ministry of Forests, Lands and Natural Resource Operations: Victoria, BC, Canada, 2017.

49. Peterson St-Laurent, G.; Hagerman, S.; Findlater, K.M.; Kozak, R. Public trust and knowledge in the context of emerging climate-adaptive forestry policies. J. Environ. Manag. 2019, 242, 474-486. [CrossRef]

50. Ledig, F.T.; Rehfeldt, G.E.; Sáenz-Romero, C.; Flores-López, C. Projections of suitable habitat for rare species under global warming scenarios. Am. J. Bot. 2010, 97, 970-987. [CrossRef]

51. Ukrainetz, N.K.; O'Neill, G.A.; Jaquish, B. Comparison of fixed and focal point seed transfer systems for reforestation and assisted migration: A case study for interior spruce in British Columbia. Can. J. For. Res. 2011, 41, 1452-1464. [CrossRef]

52. Warwell, M.V.; Rehfeldt, G.E.; Crookston, N.L. Modeling contemporary climate profiles of whitebark pine (Pinus albicaulis) and predicting responses to global warming. In Proceedings of the Conference Whitebark Pine: A Pacific Coast Perspective; Goheen, E., Ed.; R6-NR-FHP-2007-01; US Department of Agriculture, Forest Service: Ashland, OR, USA, 2007; pp. 139-142. Available online: https: / / www.fs.usda.gov/treesearch/pubs/33997 (accessed on 15 November 2020).

53. McLane, S.C.; Aitken, S.N. Whitebark pine (Pinus albicaulis) assisted migration potential: Testing establishment north of the species range. Ecol. Appl. 2012, 22. [CrossRef] [PubMed]

54. Seliger, B.J.; McGill, B.J.; Svenning, J.C.; Gill, J.L. Widespread underfilling of the potential ranges of North American trees. J. Biogeogr. 2020. [CrossRef]

55. Statistics Canada. Human Activity and the Environment: Forests in Canada 2017; Catalogue No. 16201 X; Statistics Canada: Ottawa, QC, Canada, 2018.

56. O'Neill, G.A.; Stoehr, M.; Jaquish, B. Quantifying safe seed transfer distance and impacts of tree breeding on adaptation. For. Ecol. Manag. 2014, 328, 122-130. [CrossRef]

57. Wang, T.; Hamann, A.; Spittlehouse, D.; Carroll, C. Locally downscaled and spatially customizable climate data for historical and future periods for North America. PLoS ONE 2016, 11, e0156720. [CrossRef] [PubMed]

58. O'Neill, G.A.; Hamann, A.; Wang, T. Accounting for population variation improves estimates of the impact of climate change on species' growth and distribution. J. Appl. Ecol. 2008, 45, 1040-1049. [CrossRef]

59. St. Clair, J.B.; Howe, G.T.; Kling, J.G. The 1912 Douglas-Fir heredity study: Long-term effects of climatic transfer distance on growth and survival. J. For. 2020, 118, 1-13. [CrossRef]

60. Rzedowski, J. Vegetación de México; Comisión Nacional para el Conocimiento y Uso de la Biodiversidad: Ciudad de México, México, 2006.

61. Sánchez-Velásquez, L.R.; Domínguez-Hernández, D.; Pineda-López, M.d.R.; Lara-González, R. Does Baccharis conferta shrub act as a nurse plant to the Abies religiosa seedling? Open For. Sci. J. 2011, 4, 67-70. [CrossRef]

62. Guzmán-Santiago, J.C.; Aguirre-Calderón, O.A.; Jiménez-Pérez, J.; Vargas-Larreta, B. Volume estimation of Abies religiosa (Kunth) Schltdl. \& Cham. In different states Mexico. Colomb. For. 2020, 23, 99-113. [CrossRef]

63. Anderson, J.; Brower, L. Freeze-protection of overwintering monarch butterflies in Mexico: Critical role of the forest as a blanket and an umbrella. Ecol. Entomol. 1996, 21, 107-116. [CrossRef] 
64. Montoya, E.; Guzmán-Plazola, R.A.; López-Mata, L. Fragmentation dynamics in an Abies religiosa forest of central Mexico. Can. J. For. Res. 2020, 50, 680-688. [CrossRef]

65. Carbajal-Navarro, A.; Navarro-Miranda, E.; Blanco, A.; Cruzado-Vargas, A.L.; Gómez-Pineda, E.; Zamora-Sánchez, C.; PinedaGarcía, F.; O’Neill, G.; Gómez-Romero, M.; Lindig-Cisneros, R. Ecological restoration of Abies religiosa forests using nurse plants and assisted migration in the Monarch Butterfly Biosphere Reserve, Mexico. Front. Ecol. Evol. 2019, 7, 421. [CrossRef]

66. Sáenz-Romero, C.; Rehfeldt, G.E.; Crookston, N.L.; Duval, P.; St-Amant, R.; Beaulieu, J.; Richardson, B.A. Spline models of contemporary, 2030, 2060 and 2090 climates for Mexico and their use in understanding climate-change impacts on the vegetation. Clim. Chang. 2010, 102, 595-623. [CrossRef]

67. Peterson, S.-L.G.; Hagerman, S.; Kozak, R. What risks matter? Public views about assisted migration and other climate-adaptive reforestation strategies. Clim. Chang. 2018, 151, 573-587. [CrossRef]

68. Barrows, C.W.; Ramirez, A.R.; Sweet, L.C.; Morelli, T.L.; Millar, C.I.; Frakes, N.; Rodgers, J.; Mahalovich, M.F. Validating climate-change refugia: Empirical bottom-up approaches to support management actions. Front. Ecol. Environ. 2020, 18, 298-306. [CrossRef]

69. Palmer, C.; Larson, B.M. Should we move the whitebark pine? Assisted migration, ethics and global environmental change. Environ. Values 2014, 23, 641-662. [CrossRef]

70. Pickles, B.J.; Twieg, B.D.; O'Neill, G.A.; Mohn, W.W.; Simard, S.W. Local adaptation in migrated interior Douglas-fir seedlings is mediated by ectomycorrhizas and other soil factors. New Phytol. 2015, 207, 858-871. [CrossRef]

71. Brower, L.P.; Williams, E.H.; Jaramillo-López, P.; Kust, D.R.; Slayback, D.A.; Ramírez, M.I. Butterfly mortality and salvage logging from the march 2016 storm in the Monarch Butterfly Biosphere Reserve in Mexico. Am. Entomol. 2017, 63, 151-164. [CrossRef]

72. Campbell, R.K. Use of phenology for examining provenance transfers in reforestation of Douglas-fir. J. Appl. Ecol. 1974. [CrossRef]

73. Raymond, C.; Lindgren, D. Genetic flexibility-a model for determining the range of suitable environments for a seed source. Silv. Genet. 1990, 39, 112-120.

74. Mátyás, C. Modeling climate change effects with provenance test data. Tree Physiol. 1994, 14, 797-804. [CrossRef]

75. Carter, K. Provenance tests as indicators of growth response to climate change in 10 north temperate tree species. Can. J. For. Res. 1996, 26, 1089-1095. [CrossRef]

76. Leites, L.P.; Robinson, A.P.; Rehfeldt, G.E.; Marshall, J.D.; Crookston, N.L. Height-growth response to climatic changes differs among populations of Douglas-fir: A novel analysis of historic data. Ecol. Appl. 2012, 22, 154-165. [CrossRef] [PubMed]

77. Breed, M.F.; Stead, M.G.; Ottewell, K.M.; Gardner, M.G.; Lowe, A.J. Which provenance and where? Seed sourcing strategies for revegetation in a changing environment. Conserv. Genet. 2013, 14, 1-10. [CrossRef]

78. Sáenz-Romero, C.; Lamy, J.B.; Ducousso, A.; Musch, B.; Ehrenmann, F.; Delzon, S.; Cavers, S.; Chałupka, W.; Dağdaş, S.; Hansen, J.K. Adaptive and plastic responses of Quercus petraea populations to climate across Europe. Glob. Chang. Biol. 2017, 23, 2831-2847. [CrossRef] [PubMed]

79. Berlin, M.; Persson, T.; Jansson, G.; Haapanen, M.; Ruotsalainen, S.; Bärring, L.; Andersson Gull, B. Scots pine transfer effect models for growth and survival in Sweden and Finland. Silv. Fenn. 2016, 50, 1562. [CrossRef]

80. O’Neill, G.; Carlson, M.; Berger, V.; Ukrainetz, N. Assisted Migration Adaptation Trial: Workplan; BC Ministry of Forests, Lands and Natural Resource Operations: Vernon, BC, Canada, 2013.

81. Shutyaev, A.; Giertych, M. Height growth variation in a comprehensive Eurasian provenance experiment of (Pinus sylvestris L.). Silv. Genet. 1998, 46, 332-348.

82. Shutyaev, A.; Giertych, M. Genetic subdivisions of the range of Scots pine (Pinus sylvestris L.) based on a transcontinental provenance experiment. Silv. Genet. 2000, 49, 137-151.

83. Sáenz-Romero, C.; Kremer, A.; Nagy, L.; Újvári-Jármay, É.; Ducousso, A.; Kóczán-Horváth, A.; Hansen, J.K.; Mátyás, C. Common garden comparisons confirm inherited differences in sensitivity to climate change between forest tree species. PeerJ 2019, 7, e6213. [CrossRef]

84. Marris, E. Planting the forest of the future: While conservation biologists debate whether to move organisms threatened by the warming climate, one forester in British Columbia is already doing it. Nature 2009, 459, 906-908. [CrossRef]

85. Fu, Y.-B.; Clarke, G.P.Y.; Namkoong, G.; Yanchuk, A.D. Incomplete block designs for genetic testing: Statistical efficiencies of estimating family means. Can. J. For. Res. 1998, 28, 977-986. [CrossRef]

86. Yeaman, S.; Hodgins, K.A.; Lotterhos, K.E.; Suren, H.; Nadeau, S.; Degner, J.C.; Nurkowski, K.A.; Smets, P.; Wang, T.; Gray, L.K. Convergent local adaptation to climate in distantly related conifers. Science 2016, 353, 1431-1433. [CrossRef] [PubMed]

87. Sáenz-Romero, C.; Rehfeldt, G.E.; Duval, P.; Lindig-Cisneros, R.A. Abies religiosa habitat prediction in climatic change scenarios and implications for monarch butterfly conservation in Mexico. For. Ecol. Manag. 2012, 275, 98-106. [CrossRef]

88. Etterson, J.R.; Cornett, M.W.; White, M.A.; Kavajecz, L.C. Assisted migration across fixed seed zones detects adaptation lags in two major North American tree species. Ecol. Appl. 2020, e02092. [CrossRef] [PubMed]

89. Prasad, A.; Pedlar, J.; Peters, M.; McKenney, D.; Iverson, L.; Matthews, S.; Adams, B. Combining US and Canadian forest inventories to assess habitat suitability and migration potential of 25 tree species under climate change. Divers. Distrib. 2020, 26, 1142-1159. [CrossRef]

90. Millar, C.I.; Stephenson, N.L.; Stephens, S.L. Climate change and forests of the future: Managing in the face of uncertainty. Ecol. Appl. 2007, 17, 2145-2151. [CrossRef] 
91. Lin, B.B. Resilience in agriculture through crop diversification: Adaptive management for environmental change. BioScience 2011, 61, 183-193. [CrossRef]

92. Markowitz, H.M. Portafolio selection. Finance 1952, 7, 77-91.

93. Yanchuk, A.D. A quantitative framework for breeding and conservation of forest tree genetic resources in British Columbia. Can. J. For. Res. 2001, 31, 566-576. [CrossRef]

94. Ministry of Forests, Lands, Natural Resource Operations and Rural Development. Chief Forester Standards for Seed Use 2020; Ministry of Forests, Lands, Natural Resource Operations: Victoria, BC, Canada, 2020.

95. Sgrò, C.M.; Lowe, A.J.; Hoffmann, A.A. Building evolutionary resilience for conserving biodiversity under climate change. Evol. Appl. 2011, 4, 326-337. [CrossRef]

96. Crowe, K.A.; Parker, W.H. Using portfolio theory to guide reforestation and restoration under climate change scenarios. Clim. Chang. 2008, 89, 355-370. [CrossRef]

97. Ricciardi, A.; Simberloff, D. Assisted colonization is not a viable conservation strategy. Trends Ecol. Evol. 2009, 24, 248-253. [CrossRef] [PubMed]

98. Seabrook, L.; Mcalpine, C.A.; Bowen, M.E. Restore, repair or reinvent: Options for sustainable landscapes in a changing climate. Landsc. Urban Plan. 2011, 100, 407-410. [CrossRef]

99. Mueller, J.M.; Hellmann, J.J. An assessment of invasion risk from assisted migration. Conserv. Biol. 2008, 22, 562-567. [CrossRef] [PubMed]

100. Daehler, C.C. The taxonomic distribution of invasive angiosperm plants: Ecological insights and comparison to agricultural weeds. Biol. Conserv. 1998, 84, 167-180. [CrossRef]

101. Kowarik, I. Time lags in biological invasions with regard to the success and failure of alien species. In Plant Invasions: General Aspects and Special Problems; Pyšek, P., Rejmánek, K.P.M., Wade, M., Eds.; SPB Academic Publishing: Amsterdam, The Netherlands, 1995; pp. 15-38.

102. Binggeli, P. Time-Lag between Introduction, Establishment and Rapid Spread of Introduced Environmental Weeds. In Proceedings of the III International Weed Science Congress, MS no. 8. International Weed Science Society, Oxford, UK, 6-11 June 2001.

103. Crooks, J.A. Lag times and exotic species: The ecology and management of biological invasions in slow-motion1. Ecoscience 2005, 12, 316-329. [CrossRef]

104. Camarretta, N.; Harrison, P.A.; Bailey, T.; Davidson, N.; Lucieer, A.; Hunt, M.; Potts, B.M. Stability of species and provenance performance when translocated into different community assemblages. Restor. Ecol. 2020, 28, 447-458. [CrossRef]

105. Remke, M.J.; Hoang, T.; Kolb, T.; Gehring, C.; Johnson, N.C.; Bowker, M.A. Familiar soil conditions help Pinus ponderosa seedlings cope with warming and drying climate. Restor. Ecol. 2020, 28, S344-S354. [CrossRef]

106. García-Hernández, M.d.l.Á.; Toledo-Aceves, T. Is there potential in elevational assisted migration for the endangered Magnolia vovidesii? J. Nat. Conserv. 2020, 53, 125782. [CrossRef]

107. World Meteorological Organization. WMO Provisional Statement on the State of the Global Climate in 2019; WMO: Geneva, Switzerland, 2020; p. 34.

108. Guzmán-Aguilar, G.; Carbajal-Navarro, A.; Sáenz-Romero, C.; Herrerías-Diego, Y.; López-Toledo, L.; Blanco-García, A. Abies religiosa Seedling limitations for passive restoration practices at the monarch butterfly biosphere reserve in Mexico. Front. Ecol. 2020, 13. [CrossRef]

109. Romahn-Hernández, L.F.; Rodríguez-Trejo, D.A.; Villanueva-Morales, A.; Monterroso-Rivas, A.I.; Pérez-Hernández, M.J. Altitudinal range: Forest vigor factor and determinant in the natural regeneration of the sacred fir. Entreciencias 2020, 8, 1-17. [CrossRef]

110. MacLauchlan, M.; Buxton, K. Overview of Forest Health Conditions in Southern British Columbia; Ministry of Forests, Lands and Natural Resource Operations and Rural Development: Kamloops, BC, Canada, 2018. 